Plant Tissue Cult. \& Biotech. 31(1): 97-108, 2021 (June)

(CBangladesh Assoc. for Plant Tissue Culture \& Biotechnology

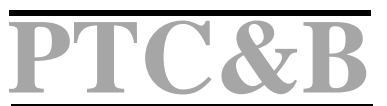

\title{
Enhanced Regeneration Through ex vitro Rooting and Agrobacterium-mediated Genetic Transformation of Eggplant (Solanum melongena L.)
}

\author{
Sabina Yesmin ${ }^{1}$, M.I. Hoque and R.H. Sarker* \\ Plant Breeding and Biotechnology Laboratory, Department of Botany, University of Dhaka, \\ Dhaka-1000, Bangladesh
}

Key words: Eggplant, Ex vitro rooting, Transformation, Agrobacterium, nptII and GUS gene

\begin{abstract}
Regeneration of in vitro multiple shoots was achieved through organogenesis on MS supplemented with $2.0 \mathrm{mg} / \mathrm{BAP}$ and $0.5 \mathrm{mg} / \mathrm{Kn}$ from cotyledonary leaf explants of two local varieties of eggplant (Solanum melongena L.). Elongation of regenerated shoots was obtained on growth regulator free MS. In vitro root induction from excised regenerated shoots was less effective on MS with or without plant growth regulators. On the other hand regenerated shoots treated with $10 \mathrm{mM}$ IBA for 5 min were found to be effective for ex vitro rooting in sterilized soil. Following sufficient development of roots, the ex vitro rooted plantlets were acclimatized in growth room condition, and were transferred to the field having $100 \%$ survival rate. The regeneration system developed was utilized for Agrobacterium-mediated genetic transformation using Agrobacterium tumefaciens strain LBA4404/pBI121 containing GUS and nptII genes. Adequate transformation response was obtained from cotyledonary leaf segments with bacterial suspension having an optical density of 0.50 at $600 \mathrm{~nm}$ with $30 \mathrm{~min}$ incubation followed by co-cultivation period of 72 hrs in Nayantara (BARI Begun-5) variety of eggplant. Selection of transformed shoots was carried out on MS supplemented with $2.0 \mathrm{mg} / \mathrm{BAP}, 0.5 \mathrm{mg} / \mathrm{Kn}, 300 \mathrm{mg} /$ carbenicillin and $100 \mathrm{mg} /$ kanamycin. Stable integration of GUS and nptII genes in Nayantara were confirmed through PCR analysis using the genomic DNA isolated from transformed shoots.
\end{abstract}

\footnotetext{
*Author for correspondence: <rhsarker2000@yahoo.co.uk>.

${ }^{1}$ This article is a part of the research findings of the first author (SY) for her higher studies leading to Ph.D. Present address: Plant Biotechnology Division, National Institute of Biotechnology, Ganak Bari, Ashulia, Savar, Dhaka-1349, Bangladesh.
}

DOI: https://doi.org/10.3329/ptcb.v31i1.54115 


\section{Introduction}

Eggplant or brinjal (Solanum melongena L., $2 \mathrm{n}=2 \mathrm{x}=24$ ) is a popular vegetable crop belonging to the family Solanaceae. This plant is a native to the Indian subcontinent and geographically distributed in different parts of Asia with the secondary center of origin in China (Zeven and Zhukovsky 1975). Eggplant is considered as the second major vegetable crop after potato in terms of acreage and production and the most important indigenous vegetable in Bangladesh (Saifullah 2012).

The fruits of eggplant are good source of vitamins and minerals as well as rich in antioxidant compounds and have hepato protective properties (Concellon et al. 2012). In traditional medicine eggplant is used for the treatment of many ailments like diabetes, arthritis, cholera, asthma and bronchitis (Magioli and Mansur 2005). Moreover, the texture of the fruit of different varieties of eggplant makes it more popular vegetable food item in wide range of dishes.

Eggplant is an important source of income for the small, marginal and resource poor farmers in Bangladesh. It is grown by about 1,50,000 very small resource poor farmers in Bangladesh.This crop is cultivated in about $25 \%$ of the total land under vegetable cultivation in Bangladesh. For most of the time, except peak production period, market price of eggplant remains high compared to other vegetables. Therefore, it plays a vital role to boost the national economy (Hossain et al. 2013) in Bangladesh.

It is understood that eggplant is an important vegetable crop of Bangladesh and several different indigenous varieties of eggplant cultivated in different areas of Bangladesh. However, the yield potentials of different varieties of eggplant is found to be variable and the yield of this important vegetable crop is appeared to be affected significantly by various kinds of biotic and abiotic stresses. The biotic stresses includes the infestation of diseases and pests while the abiotic stresses that hampering its productivity includes the effects of drought, salinity, flood, cold and heat stress (Prabhavathi and Rajam 2007).

In the past, several attempts have been made through conventional breeding for the development of stress tolerance in eggplant and to transfer of desired traits into its cultivated species. Conventional breeding approaches through hybridization for developing desired stress tolerance in eggplant is limited due to sexual incompatibilities, prevalence of sterility in the progeny and lack of natural sources of resistance (Shivraj and Rao 2011, Magioli and Mansur 2005). Under these circumstances the techniques of plant genetic engineering can be exploited for the development of desired stress tolerance in eggplant and thus the difficulties associated with conventional method of breeding for the transfer of desired traits can be avoided.

Among the various techniques Agrobacterium-mediated genetic transformation has been considered as a method of choice for the transfer of desired genes (Zambryski 1982). In the present investigation, efforts were made to establish a suitable protocol for Agrobacterium-mediated genetic transformation in popular eggplant varieties of 
Bangladesh using both screenable and selectable marker genes as an aid to incorporate suitable stress tolerant genes in these varieties of eggplant in the future research program. Apart from these in vitro regeneration of plantlets was carried out to facilitate Agrobacterium-mediated genetic transformation in popular eggplant varieties of Bangladesh.

\section{Materials and Methods}

Two local varieties of eggplant (Solanum melongena L.) such as, Nayantara (BARI begun5) and Kazla (BARI begun-4) were used as experimental materials for this investigation. Seeds of these varieties were obtained from the Vegetable Seed Division of Bangladesh Agricultural Research Institute (BARI), Joydebpur, Gazipur.

The procedures for the sterilization of seeds, germination of seeds, and preparation of explants, in vitro regeneration as well as rooting were carried out following in protocols developed by Sarker et al. (2006). The cotyledonary leaf explants were cultured on MS with various concentrations and combinations of BAP and $\mathrm{Kn}$ for in vitro regeneration of shoots through organogenesis. The $\mathrm{pH}$ of the regeneration medium was adjusted to 5.8 before autoclaving. Cultures were incubated and maintained in growth room with a fixed photoperiod of $16 / 8 \mathrm{hrs}$ dark/ight cycle at $25 \pm 1^{\circ} \mathrm{C}$. For ex vitro rooting, the in vitro raised shoots were separated out from the culture vessels and cut obliquely at the base. Then the base of excised shoots was dipped into $10 \mathrm{mM}$ IBA solution for five minutes and transferred to small plastic pots containing moist sterilized soil. These pots were then covered with transparent perforated polythene bags and were kept in growth room for two weeks. After two weeks the cover was removed and the plantlets were hardened during the next week.

Genetic transformation was performed using Agrobacterium tumefaciens strain LBA4404 harboring binary plasmid pBI121 containing a scoreable reporter gene GUS ( $\beta$ glucuronidase) driven by CaMV promoter and a selectable marker gene, nptII encoding for the enzyme neomycin phosphotransferase. This reporter gene was used in assessing the efficiency of transformation. A small amount of glycerol stock (preserved in $-80^{\circ} \mathrm{C}$ refrigerator) of Agrobacterium-strain was streaked on solid YEP medium and incubated at $28^{\circ} \mathrm{C}$ for $48 \mathrm{hrs}$. After $48 \mathrm{hrs}$ a single colony of Agrobacterium tumefaciens was picked from plate and again streaked on a new YEP medium. After $48 \mathrm{hrs}$ the bacteria were taken from the plate and dissolved in $30 \mathrm{ml}$ of liquid MS containing $9 \%(\mathrm{w} / \mathrm{N})$ sucrose. Bacterial suspension having optical density (OD) of $0.3,0.5$ and 0.8 were chosen for transformation. The wave length of optical density (OD) of this suspension was determined at $600 \mathrm{~nm}$ with the help of a spectrophotometer (Shimadzu, Japan). 100 $\mu \mathrm{mol} / \mathrm{l}$ acetosyringone was added to the Agrobacterium suspension before infection.

The cotyledonary leaf explants were precultured on regeneration medium (RM) containing $2.0 \mathrm{mg} / \mathrm{BAP}+0.5 \mathrm{mg} / \mathrm{Kn}$ for $48 \mathrm{hrs}$. After $48 \mathrm{hrs}$ the explants were dipped in the bacterial suspension and incubated for variable time periods (20, 30 and $40 \mathrm{~min}$ ). 
After incubation the explants were transferred to co-cultivation medium (MS $+2.0 \mathrm{mg} /$ $\mathrm{BAP}+0.5 \mathrm{mg} / \mathrm{Kn}+100 \mu \mathrm{mol} / \mathrm{l}$ acetosyringone) and incubated for 2, 3 and 4 days at $25 \pm$ $2^{\circ} \mathrm{C}$ in an incubator in the dark. After co-cultivation the explants were thoroughly washed with sterilized distilled water for 4 - 5 times and finally washed for 10 mins with distilled water containing $300 \mathrm{mg} /$ carbenicillin. After that the explants were transferred to selection medium containing MS supplemented with $2.0 \mathrm{mg} / \mathrm{BAP}, 0.5 \mathrm{mg} / \mathrm{Kn}, 100$ $\mathrm{mg} /$ Kanamycin and $300 \mathrm{mg} /$ carbenicillin. Explants were sub-cultured on the same selection medium at a regular interval of three to four weeks. After 45 to 50 days of infection, the green compact callus was found to develop at the cut ends of explants. These green calli were further sub-cultured and maintained on same selection medium until the shoots were developed. After $100-110$ days small shoots and shoot buds were subcultured to MS basal medium for proliferation and elongation of shoots. Elongated (2.5 - $4 \mathrm{~cm}$ long) shoots were excised and used for ex vitro root induction. After 3 to 4 weeks, plantlets with well-developed root system were transplanted to large earthen pots containing soil and organic manure $(5: 1)$ for further growth and development in the greenhouse condition.

Following each transformation experiment, randomly selected ten co-cultured explants were exposed for GUS histochemical assay to determine the efficiency of transformation using X-gluc (5-bromo-4-chloro-3-indolyl- $\beta$-D glucuronide) solution and incubated at $37^{\circ} \mathrm{C}$ for $24-48 \mathrm{hrs}$. After treatment, explants and plant parts were bleached with $70 \%$ ethanol to remove chlorophyll before scoring GUS expression. Leaves, shoots, roots, flower, anther, pollen grain and germinated seedlings were assayed from randomly selected transformed and control (wild) plants.

The genomic DNA was extracted from the young leaves of matured transformed and one non-transformed (control) plants using CTAB method (Doyle and Doyle 1990). Plasmid DNA of pBI121 was used as positive control. Presence of introduced GUS and nptII genes were detected by PCR analysis (eppendorf Master Cycler Gradient, Germany). The gene-specific primers for GUS gene 5'CATGAAGATGCGGACTTACG-3' and $3^{\prime}$-ATCCACGCCGTATTCGGCGT-5' were used as forward and reverse at a concentration of $10 \mathrm{pmol} / \mu \mathrm{l}$. For the confirmation of the nptII gene, DNA was subjected to PCR analysis using 5'TAGCTTCTTGGG TATCTTTAAAATA-3'and 3'-CCAGTTA CCTTCGGAAAAAGAGTT5', as forward and reverse primer respectively. For $25 \mu 1$ PCR reaction $0.2 \mu \mathrm{l}$ Taq DNA polymerase, $10 \times 2.5 \mu \mathrm{l}$ buffer and $0.5 \mu \mathrm{l}$ dNTPs were used. For GUS gene DNA was denatured at $95^{\circ} \mathrm{C}$ for $5.0 \mathrm{~min}$, followed by 30 amplification cycles. Each cycle was programmed with three different thermal periods: at $95^{\circ} \mathrm{C}$ for $1.0 \mathrm{~min}$ to denature DNA, at $56^{\circ} \mathrm{C}$ for $30 \mathrm{sec}$ to anneal the primer and at $72^{\circ} \mathrm{C}$ for $1.0 \mathrm{~min}$ for the extension or elongation of DNA by Taq DNA polymerase. For nptII gene DNA was denatured at $95^{\circ} \mathrm{C}$ for $5.0 \mathrm{~min}$, followed by 30 amplification cycles using $95^{\circ} \mathrm{C}$ for $1.0 \mathrm{~min}$ (denaturation), $55^{\circ} \mathrm{C}$ for $1.0 \mathrm{~min}$ (annealing) and $72^{\circ} \mathrm{C}$ for $1.0 \mathrm{~min}$ (extension). The final extension lasted for $10 \mathrm{~min}$ at $72^{\circ} \mathrm{C}$ to allow complete extension of all amplified fragments. After completion of cycling program, reaction was held at $4^{\circ} \mathrm{C}$. The amplified 
DNA was electrophoresed on $1.0 \%(\mathrm{w} / \mathrm{N})$ agarose gel containing ethidium bromide $(0.08$ $\mu \mathrm{l} / \mathrm{ml}$ ) for $40 \mathrm{~min}$. The gel was photographed under UV light using gel documentation system (Bio.Sci.Tech.Gelscan, 6.0. Professional, Germany).

\section{Results and Discussion}

Different concentrations and combinations of BAP and $\mathrm{Kn}$ were used in MS to examine their effects on initiation and development of shoots from cotyledonary leaf explant. Transformation compatible high frequency uniform in vitro regeneration of shoots was achieved on MS supplemented with $2.0 \mathrm{mg} / \mathrm{BAP}$ and $0.5 \mathrm{mg} / \mathrm{Kn}$ for both the varieties of eggplant studied (Table 1). Almost similar results were reported earlier by Shivaraj and Rao (2011) in different set of varieties of eggplant. Development of shoots from cotyledonary leaf explants from the variety Nayantara has been presented in Fig. 1.

Table 1. Effect of different concentrations and combinations of BAP and $\mathrm{Kn}$ on in vitro regeneration of multiple shoot from cotyledonary leaf explants of two varieties of eggplant (Kazla Nayantara).

\begin{tabular}{|c|c|c|c|c|c|c|}
\hline \multicolumn{2}{|c|}{$\begin{array}{l}\text { Concentrations } \\
(\mathrm{mg} \Lambda)\end{array}$} & Varieties & $\begin{array}{l}\% \text { of } \\
\text { responsive } \\
\text { explants }\end{array}$ & $\begin{array}{l}\text { Days required } \\
\text { for initiation of } \\
\text { regeneration }\end{array}$ & $\begin{array}{l}\% \text { of shoot } \\
\text { forming } \\
\text { explants }\end{array}$ & $\begin{array}{c}\text { Mean no. of } \\
\text { shoots /explants } \\
\text { after } 6 \text { - } 8 \text { weeks }\end{array}$ \\
\hline BAP & Kn & & Mean & & Mean & Mean \pm SE \\
\hline \multirow[t]{2}{*}{0.5} & 0.5 & Kazla & 73 & $12-13$ & 47 & $1.87 \pm 0.21$ \\
\hline & & Nayantara & 70 & $13-14$ & 45 & $2.27 \pm 0.24$ \\
\hline \multirow[t]{2}{*}{1.0} & 0.5 & Kazla & 80 & $11-12$ & 50 & $2.47 \pm 0.29$ \\
\hline & & Nayantara & 80 & $11-12$ & 50 & $2.8 \pm 0.29$ \\
\hline \multirow[t]{2}{*}{1.0} & 1.0 & Kazla & 90 & $10-12$ & 60 & $3.70 \pm 0.31$ \\
\hline & & Nayantara & 87 & $9-10$ & 63 & $3.60 \pm 0.37$ \\
\hline \multirow[t]{2}{*}{2.0} & 0.5 & Kazla & 100 & $9-10$ & 73 & $4.33 \pm 0.50$ \\
\hline & & Nayantara & 97 & $8-10$ & 77 & $4.70 \pm 0.43$ \\
\hline \multirow[t]{2}{*}{2.0} & 1.0 & Kazla & 88 & $10-11$ & 45 & $2.66 \pm 0.23$ \\
\hline & & Nayantara & 90 & $10-11$ & 45 & $2.53 \pm 0.23$ \\
\hline
\end{tabular}

The best initiation of shoot buds from cotyledonary leaf explants of Nayantara was achieved on MS supplemented with $2.0 \mathrm{mg} \Lambda \mathrm{BAP}$ and $0.5 \mathrm{mg} \Lambda \mathrm{Kn}$. Initiation of regeneration from these explants occurred within 10 - 11 days of culture (Fig. 1a) and the formation of multiple shoots was achieved within 20 to 25 days from the initiation (Fig. 1b). Almost all the explants were found to respond (100\% in case of Kazla and $97 \%$ in Nayantara) in this combination of hormonal supplements. Moreover, 73 and $77 \%$ of the 
responsive explants produced multiple shoots in case of the varieties Kazla and Nayantara respectively. The mean number of developing shoots recorded after six weeks of culture were $4.33 \pm 0.50$ and $4.70 \pm 0.43$ in case of the variety Kazla and Nayantara respectively (Table 1). In this case, further elongation and proliferation of multiple shoots were done in hormone free MS medium (Fig. 1c).
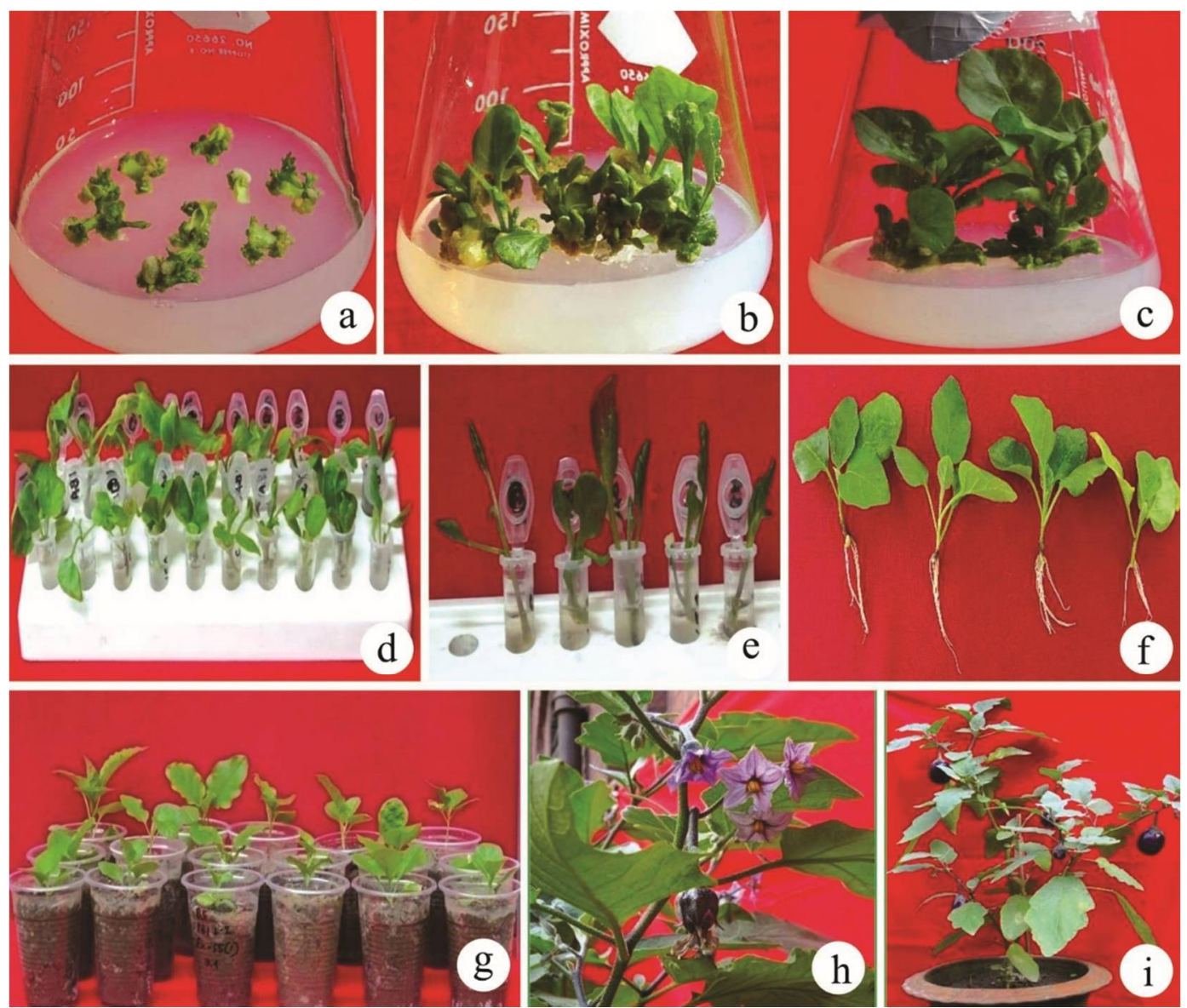

Fig. 1 (a-i). In vitro shoot regeneration and ex vitro rooting of regenerated shoots of two varieties of eggplant from cotyledonary leaf explants: a. Initiation of shoot buds from cotyledonary leaf explants of Nayantara on MS with $2.0 \mathrm{mg} / \mathrm{BAP} \& 0.5 \mathrm{mg} / \mathrm{Kn}$. b. Initiation of multiple shoots on the same media as mentioned in Fig. 1 a. c. Development and elongation of shoots of Nayantara on hormone free MS basal medium. d. Incubation of regenerated shoots in $10 \mathrm{mM}$ IBA solution for ex vitro rooting of Nayantara. e. Same as Fig. 1d but in case of regenerated vitrified shoots. f. Ex vitro rooted plantlets of Nayantara developed after 21 days of IBA treatment. g. Ex vitro rooted plantlets of Nayantara in small plastic pots. h. In vitro derived plant of Nayantara flowering and fruit setting after four weeks following transplantation. i. Same as Fig. 1h but showing fully mature plant bearing several fruits. 
In the present investigation it was observed that presence of cytokinin in the culture medium for a longer period inhibited the induction of in vitro roots from the excised regenerated shoots. Vitrification of shoots were also found to be associated with this event. Such effects of the presence of residual cytokinins in eggplant culture were also reported by Muktadir et al. (2016). In hormone free MS about $70 \%$ of the regenerated shoots produced roots but the development of such roots was not synchronized and appeared to be irregular in both the varieties.

However, a number of reports are available where IBA was used for adventitious root formation from regenerated shoots of eggplant (Muktadir et al. 2016, Bhat et al. 2013, Shivraj and Rao 2011). In this study about $85 \%$ shoots were found to produce roots on MS supplemented with $2.0 \mathrm{mg} / \mathrm{IBA}$, but such root formation was found to be ineffective as it was associated with vigorous growth of callus at the base of excised shoot. Further the internode of the cultured shoots for rooting increased rapidly and as a result the shoots became pale green in color and turned fragile in nature. To overcome this problems, ex vitro rooting of regenerated shoots of both varieties of eggplant were explored. In a number of medicinal plants IBA treatment was reported to be effective for ex vitro root induction (Shekhawat and Manokari 2018, Sharma et al. 2017). In vitro regenerated and transformed shoots as well as vitrified shoots of both varieties of eggplant were found to produce roots within 7 to 12 days following $5.0 \mathrm{~min}$ incubation of detached shoots in $10 \mathrm{mM}$ IBA solution (Table 2, Figs. 1d-1e). So far there is no previous report on ex vitro rooting of in vitro regenerated shoots of eggplants. After three weeks of maintenance, $93.33 \%$ regenerated shoots of Kazla and $96.66 \%$ that of Nayantara produced well developed root system at the base of regenerated shoots (Fig. 1f). In addition, after four weeks of culture, 60 to $67 \%$ vitrified shoots of both varieties produced healthy roots and such shoots turned to normal green in color under ex vitro condition. Ex vitro rooted plantlets were hardened and acclimatized within four weeks (Figs. 1g). After sufficient development of roots plantlets of both varieties were transferred to large earthen pots containing soil and organic manure $(5: 1)$. In the greenhouse condition $100 \%$ plants were survived and these plants flowered after four weeks and producing fruits with viable seeds (Figs. $1 \mathrm{~h}$ and 1i). These protocols for in vitro shoot regeneration as well as ex vitro rooting developed for eggplant varieties were utilized for transformation experiments.

To develop an effective transformation system for eggplant, the variety Nayantara was used during this study. Several parameters required for transformation such as optical density of the Agrobacterium suspension, incubation period, co-cultivation period of explants were optimized for the variety Nayantara. All the parameters of transformation were optimized through GUS histochemical assay. Transformation efficiency of explants was gradually increased with the increased optical density (OD600) $(0.3,0.5$ and 0.8). Cotyledonary leaf segments showed maximum percentage of transformed explants at an optical density of 0.5 (85\% GUS positive, data not shown). Different incubation periods, such as 10, 20 and 30 minutes were applied using bacterial 
suspension with a constant optical density of 0.50 . From these results it was evident that transformation efficiency increased with the increase of incubation period of explants. Maximum percentage of the transformed explants (100\% GUS positive) was observed with an incubation period of 30 minutes. Borna et al. (2010) used 0.8 OD of Agrobacterium suspension, 40 minutes of infection period and co-culture period of for 3 days in establishing transformation protocol for potato. Duration of co-cultivation was found to influence the transformation efficiency and 3 days was found to be most suitable. Pratap et al. (2011) reported identical responses for eggplant transformation using cotyledonary leaf explants where 30 minutes of incubation in Agrobacterium suspension followed 2-day of co-cultivation was found to be effective.

Table 2. Effects of $10 \mathrm{mM}$ IBA treatment on ex vitro root induction from regenerated shoots of two varieties of eggplant on sterilized soil (Data were recorded after three weeks of culture).

\begin{tabular}{|c|c|c|c|c|c|c|}
\hline $\begin{array}{l}\text { Duration of } \\
\text { time of IBA } \\
\text { treatment } \\
\text { (min) }\end{array}$ & Variety & $\begin{array}{l}(\%) \text { of } \\
\text { rooted } \\
\text { shoots }\end{array}$ & $\begin{array}{c}\text { Days } \\
\text { required } \\
\text { to initiate } \\
\text { roots }\end{array}$ & $\begin{array}{c}\text { Days required } \\
\text { to obtain well } \\
\text { developed } \\
\text { roots }\end{array}$ & $\begin{array}{l}\text { No. of } \\
\text { roots / } \\
\text { shoot }\end{array}$ & $\begin{array}{l}\text { Length of } \\
\text { roots }(\mathrm{cm})\end{array}$ \\
\hline & & Mean & & & Mean \pm SE & Mean \pm SE \\
\hline \multirow[t]{2}{*}{5.0} & Kazla & 93 & $7-8$ & $20-21$ & $8.90 \pm 0.66$ & $2.64 \pm 0.07$ \\
\hline & Nayantara & 97 & $8-10$ & $20-21$ & $9.20 \pm 0.74$ & $2.95 \pm 0.08$ \\
\hline \multirow[t]{2}{*}{5.0} & Kazla (vitrified shoots) & 67 & $13-15$ & $28-30$ & $7.90 \pm 0.62$ & $2.52 \pm 0.12$ \\
\hline & $\begin{array}{l}\text { Nayantara(vitrified } \\
\text { shoots) }\end{array}$ & 60 & $13-15$ & $28-30$ & $8.40 \pm 0.56$ & $2.57 \pm 0.12$ \\
\hline
\end{tabular}

After co-cultivation, the cotyledonary leaf explants were cultured on MS medium containing $2.0 \mathrm{mg} / \mathrm{BAP} 0.5 \mathrm{mg} / \mathrm{Kn}, 100 \mathrm{mg} /$ Kanamycin and $300 \mathrm{mg} /$ carbenicillin for regeneration of shoots and after six to seven weeks from co-cultivation initiation of shoot regeneration was observed. The results of transformation experiments have been presented in Fig. 2. Kanamycin $(100 \mathrm{mg} /)$ was found to be effective in selecting the transformed shoots. About 51\% of co-cultured explants were survived and showed initiation of regeneration at the cut ends of explants (Fig. 2a). Due to Kanamycin selection the non-transformed explants as well as a part of several explants gradually turned yellow to brown in colour and such tissue was discarded during the subculture. In this experiment, the effect of kanamycin selection was adequate when it was applied immediately after co-cultivation of infected explants as has been experienced by Franklin and Sita (2003). Following subculture of survived healthy explants the initiation of regeneration was visualized under stereomicroscope (Fig. 2b). Initiation of shoots was observed after 11-12 weeks of co-cultivation of explants (Fig. 2c). It was found that all the responsive explants didn't produce shoots and only $32 \%$ of infected explants finally able to produce multiple shoots with efficiency of $2-3$ shoots per explant. For proliferation and elongation of shoots, the small green shoots along with the shoot buds were further 
transferred to fresh MS containing $100 \mathrm{mg} /$ kanamycin (Fig. 2d). Following elongation the shoots $(2.5-4.0 \mathrm{~cm}$ long) were subjected to ex vitro rooting for three to four weeks (Fig. 2e). After four weeks the rooted and acclimatized putatively transformed plantlets were transplanted to large earthen pot. Following transplantation, the plants were flowered after 4 - 5 weeks and found to produce fruits with viable seeds (Fig. 2f).
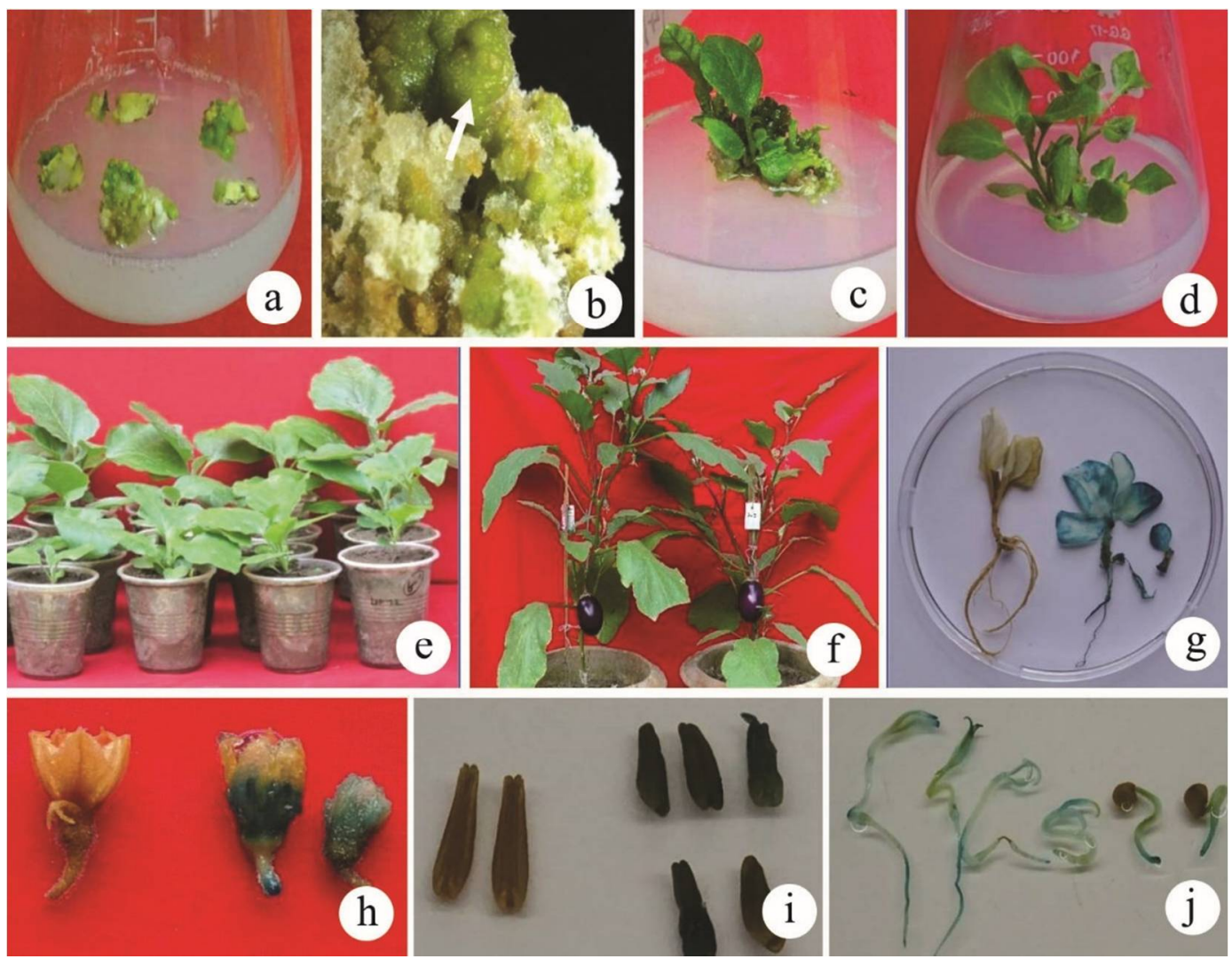

Fig. 2. Various stages of development of transformed plantlets from cotyledonary leaf explants following Agrobacterium-mediated transformation in variety Nayantara. a. Initiation of regeneration from cotyledonary leaf explants after 5-6 weeks of infection b. Stereoscopic view of green compact callus of cotyledonary leaf explants after 7 weeks of infection (arrow indicates the formation of shoot buds). c. Initiation of shoots after 10 weeks of infection. d. Fully developed shoots after 14 weeks of infection. e. Ex vitro rooted fully developed putatively transformed plantlets on small plastic pot containing sterilized soil. f. Fruits set in putatively transformed plantlets on large earthen pots. g. GUS expression of transgenic plantlets (blue in colour) with a control one (white in colour). h. Flowers from To plant showing GUS expression with a control. i. Anthers of putative To plant showing GUS expression with control. j. Seedlings from $\mathrm{T}_{1}$ plants showing GUS expression (blue colour). Note that the control materials in all Figs. did not produce characteristic blue colour of GUS expression. 
GUS histochemical assay was carried out at every steps of shoot development during the transformation to monitor the efficiency of transformation. Stable expression of GUS gene was visualized through histochemical staining of the transformed rooted shoots (Fig. 2g). The floral parts (petals, anthers and stigma) also exhibited the characteristic blue colour indicating the stable integration of GUS gene in the transformed plants (Figs. $2 \mathrm{~h}-2 \mathrm{i})$. Moreover, the $\mathrm{T}_{1}$ seedlings showed GUS positive expressions which confirms the successful insertion of GUS genes into the advanced progeny obtained from the transformed ( $\left.\mathrm{T}_{0}\right)$ plants (Fig. 2j).

The transgenic nature of the transformed plants was confirmed through PCR analysis using the primers of GUS and nptII genes respectively (Figs. 3a, b). Genomic DNA from 18 randomly selected transformed plants, one wild type plant and pBI121 plasmid DNA were used as template for the PCR. From the gel it was evident that both GUS and nptII genes were inserted in the genomic DNA of 18 transformed plantlets exhibiting very clear and prominent band identical to positive control (pBI121) used for GUS and nptII genes.
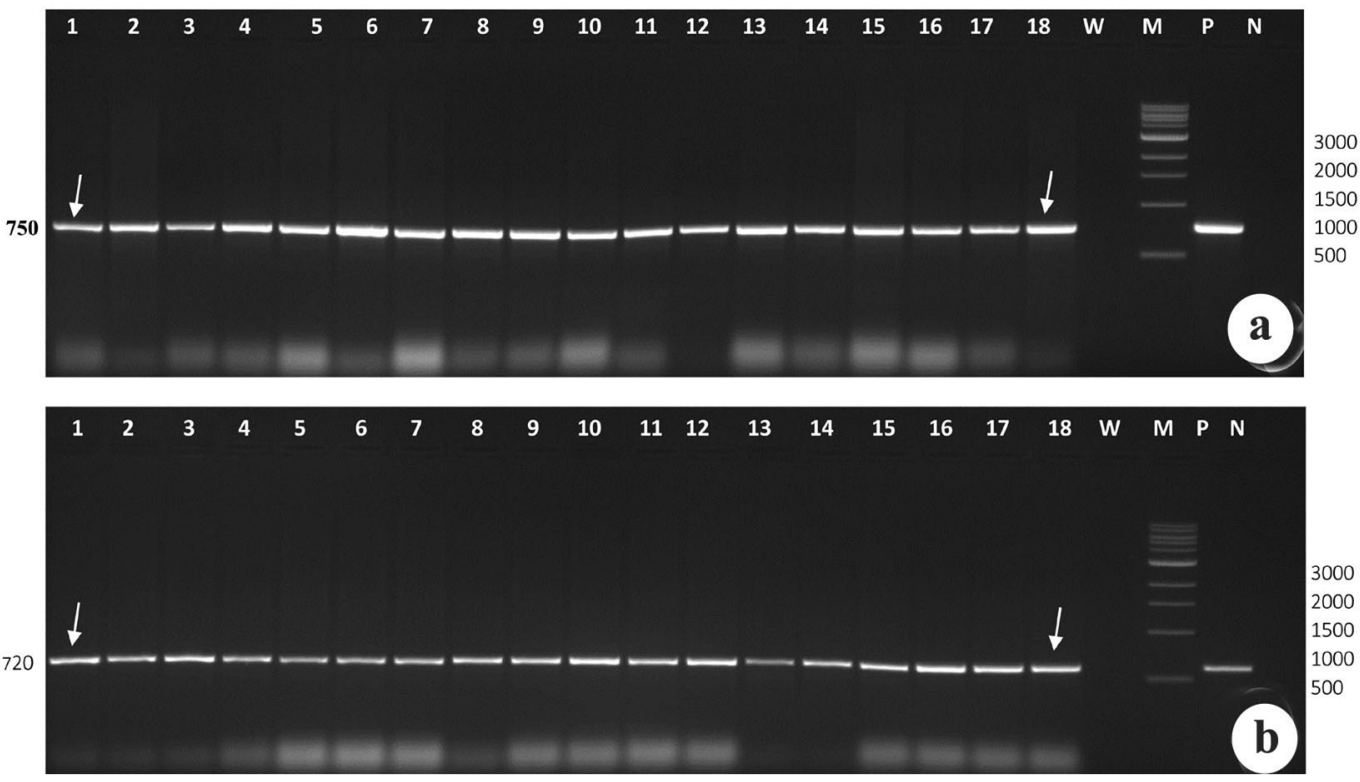

Fig. 3 ( $\mathrm{a}-\mathrm{b}$ ): Agarose gel showing the PCR amplified bands for GUS and nptll genes. a. Molecular characterization of the putative transformants of Nayantara variety through PCR amplification of GUS genes (lanes 1-18 genomic DNA of transformed shoots; lane W- wild type; lane M- 1kb ladder; lane P- plasmid DNA of pBI121 as positive control; lane N- negative control). b. Same as Fig. a but for nptII gene.

In conclusion, it may be mentioned that an efficient and reproducible Agrobacterium tumefaciens- mediated transformation protocol was established for eggplant varieties of Bangladesh using cotyledonary leaf as explants using screenable (GUS) and selectable 
(nptll) marker genes. Following this standardized protocol various other agronomically important gene/genes can be transferred to the locally grown eggplant varieties. Particularly this technique of transformation can be utilized for the development of salinity and drought tolerant eggplant varieties which will certainly contribute significantly in future agriculture of Bangladesh.

\section{Acknowledgement}

The first author is grateful to National Institute of Biotechnology, Ganakbari, Ashulia, Savar, Dhaka-1349 for granting her study leave and the Ministry of Science and Technology, Govt. of the People's Republic of Bangladesh for providing financial support through Bangabandhu Science \& Technology Fellowship program. She is also thankful to Prof. Dr. Mohammad Nurul Islam, Dr. Rita Sarah Borna, and Dr. Tahmina Islam, Department of Botany, University of Dhaka for their valuable advice and encouragement during this investigation.

\section{References}

Bhat SV, Jadhav AS, Pawar BD, Kale AA, Chimote VP and Pawar SV (2013) In vitro shoot organogenesis and plantlet regeneration in brinjal ((Solanum melongena L.). The Bioscan 8(3): 821-824.

Borna RS, Hoque MI and Sarker RH (2019) In vitro microtuber induction and regeneration of plantlets from microtuber discs of cultivated potato (Solanum tuberosum L.). Plant Tissue Cult. Biotech. 29(1): 63-72.

Concellon A, Zaro MJ, Chaves AR and Vicente AR (2012) Changes in quality and phenolic antioxidants in dark purple American eggplant (Solanum melongena L. cv. Lucía) as affected by storage at $0{ }^{\circ} \mathrm{C}$ and $10^{\circ} \mathrm{C}$. Postharvest Biol. Tec. 66: 35-41.

Doyle JJ and Doyle JL (1990) Isolation of plant DNA from fresh tissue. Focus 12(13): 39-40.

Franklin G and Sita GL (2003) Agrobacterium tumefaciens-mediated transformation of eggplant (S. melongena L.) using root explant. Plant Cell Rep. 21: 549-554.

Hossain MI, Islam MR, Uddin MN, Arifuzzaman SM and Hasan GN (2013) Control of phomopsis blight of eggplant through fertilizer and fungicide management Int. J. Agril. Res. Innov. \& Tech. 3(1): 66-72.

Magioli C and Mansur E (2005) Eggplant (Solanum melongena L.): tissue culture, genetic transformation and use as an alternative model plant. Acta. Bot. Bras. 19: 139-148.

Muktadir MA, Habib MA, Mian MAK and Akhond AY (2016) Regeneration efficiency based on genotype, culture condition and growth regulators of eggplant (Solanum melongena L.). Agriculture and natural resources 50: 38-42.

Probhavathi V and Rajam MV (2007) Polyamine accumulation in transgenic eggplant enhances tolerance to multiple abiotic stresses and fungal resistance. Plant Biotechnol. 24: 273-282.

Pratap D, Kumar S, Krishna SR and Sharma AK (2011) Agrobacterium-mediated transformation of eggplant (Solanum melongena L.) using cotyledon explants and coat protein gene of Cucumber mosaic virus. Indian Journal of Biotechnology 10: 19-24. 
Shivraj G and Rao S (2011) Rapid and efficient regeneration of eggplant (Solanum melongena L). Indian J. Biotechnol. 10: 125-129.

Saifullah M, Goffar MA, Ahmad S and Bhuya MAJ (2012) Utilization of indigenous vegetables for sustainable vegetable production in Bangladesh. International symposium on Sustainable vegetable production in Southeast Asia, Salatiga, Indonesia August 2012.

Sharma U, Kataria V and Shekhawat NS (2017) In vitro propagation, ex vitro rooting and leaf micromorphology of Bauhinia racemosa Lam.: a leguminous tree with medicinal values. Physiol Mol. Biol. Plants 23(4): 969-977.

Shekhawat MS and Manokari M (2018) In vitro multiplication, micromorphological studies and $e x$ vitro rooting of Hybanthusenneaspermus (L.) F. Muell. - a rare medicinal plant. Acta Bot. Croat. 77 (1): 80-87.

Sarker RH, Yesmin S and Hoque MI (2006) Multiple shoot formation in eggplant (Solanum melongena L.). Plant Tiss. Cult. Biotech. 16(1): 53-61.

Zambryski P, Depicker A, Kruger K and Goodman HM (1982) Tumor induction by Agrobacterium tumefaciens: Analysis of the boundaries of T-DNA. J. Mol. Appl. Genet. 1: 361-370.

Zeven AC and Zhukovsky PM (1975) Dictionary of cultivated plants and their centre of diversity, Wageningen, Netherlands. p. 219.

(Manuscript received on 10/05/2021; revised on 30/05/2021) 